\title{
A Conceptual Analysis of the Role of Knowledge Management in Knowledge Leadership
}

\section{Bilgi Yönetiminde Bilgi Liderliğinin Rolü Üzerine Kavramsal Bir Analiz}

\author{
Ender KAZAK ${ }^{*}$
}

Received: 08 January 2021

Research Article

Accepted: 03 June 2021

\begin{abstract}
Knowledge-based organizational structures need leaders who manage and ensure the effectiveness of knowledge. Knowledge leaders encourage employees to participate in knowledge management processes, contribute to adopting knowledge management as part of organizational culture, and lead knowledge management activities by choosing the most appropriate infrastructure and technology. Schools are knowledge-intensive organizations that possess a large number of information areas that must be managed. The main actors who are responsible for managing these areas of knowledge are school principals. This situation requires school principals to be competent in terms of both knowledge management and leadership skills. The purpose of this study is to make a conceptual evaluation of the relationship between knowledge leadership and knowledge management. To achieve this aim, the relationships between knowledge leadership and knowledge management were examined, a conceptual evaluation of these relationships was made, and the importance of knowledge leadership both at the organizational level and the school level was emphasized. Designed as a theoretical literature review, it investigates the hypothesis that knowledge leaders undertake important roles in knowledge management processes. Therefore, the study is important for understanding the role of knowledge leaders in knowledge management.
\end{abstract}

Keywords: Knowledge management, knowledge leadership, school principal.

ÖZ: Bilgiye dayanan örgüt yapıları, bilginin etkililiğini sağlayacak ve yönetecek liderlere gereksinim duyarlar. Bilgi liderleri, bilgi yönetimi sürecinde işgörenlerin katılımını sağlayan, bilgi yönetiminin bir örgüt kültürü olarak yerleşmesine katkıda bulunan ve bilgi yönetimi için uygun alt yapı ve teknolojinin seçimini sağlayarak bilgi yönetimi faaliyetlerini yönlendiren kişilerdir. Okullar, bilgi yoğun örgütlerdir ve yönetilmesi gereken çok sayıda bilginin varlığından söz edilebilir. Bu bilgileri yönetecek baş aktörler ise okul müdürleridir. Bu durum, okul müdürlerinin hem bilgi yönetimi hem de liderlik becerileri açısından yetkin olmasını gerektirmektedir. Bu çalışmanın amacı, bilgi liderliği ile bilgi yönetimi arasındaki ilişkiyi irdelemek ve bu ilişkilere yönelik kavramsal bir değerlendirme yapmaktır. Bu amaç doğrultusunda bilgi liderliği ile bilgi yönetimi arasındaki ilişkiler incelenmiş, bu ilişkilere ilişkin kavramsal bir değerlendirme yapılmış ve hem örgütsel hem de okul düzeyinde bilgi liderliğinin önemi vurgulanmıştır. Çalışma, alanyazın taraması şeklinde gerçekleştirilmiştir. Çalışmanın varsayımı; bilgi yönetimi süreçlerinde bilgi liderlerinin önemli rol ve sorumlulukları olduğu yönündedir. Bu nedenle çalışma, bilgi yönetiminde bilgi liderlerinin rolünün anlaşılması açısından önemlidir.

Anahtar kelimeler: Bilgi yönetimi, bilgi liderliği, okul müdürü.

\footnotetext{
* Corresponding Author: Assoc. Prof. Dr., Düzce University, Düzce, Turkey, enderkazak81@hotmail.com, https://orcid.org/0000-0001-5761-6330
}

Citation Information

Kazak, E. (2021). A conceptual analysis of the role of knowledge management in knowledge leadership. Kuramsal Eğitimbilim Dergisi [Journal of Theoretical Educational Science], 14(3), 352-372. 
Modern society is based on knowledge. Today, knowledge is the most soughtafter commodity, the most valuable resource of an organization, and a means of competitive advantage. Knowledge is the driving force that enlivens the efficient use of all resources within the organization. Knowledge is the only resource which does not decrease by sharing; in contrast, by using and sharing it, the organizations' general knowledge expands (Micić, 2015). However, knowledge must be managed. Organizations need effective knowledge management to continue to compete. In this sense, leadership plays an important role. Leadership should exist at all organizational levels and encourage knowledge management actions. If leaders do not have direct support at all levels, it is difficult for knowledge management actions to reach the desired performance level (Besen et al., 2017). The role of leadership in knowledge management practices is crucial to motivate employees to share knowledge (MasMachuca, 2014). Studies show that both the effectiveness of leaders and knowledge sharing behavior affect the job performance of employees within an organization positively (Sönmez Çakır \& Adıgüzel, 2020). The implementation of knowledge management in schools can help school leaders benefit from best practices in terms of problem-solving, retaining information for future use, and filling the knowledge gap in development plans for school improvement (Cheng et al., 2017).

\section{Method}

\section{Research Model}

This study was designed as a descriptive research in survey model. Survey models are research approaches which aim to describe a past or present situation in the way it occurs (Karasar, 1999). In this study, a descriptive survey model was preferred because the concepts of knowledge management and knowledge leadership, and the relationship between them, were discussed in the light of related studies.

\section{Purpose of the Research}

The main purpose of this study was to discuss the role of knowledge leaders in knowledge management theoretically. In line with this aim, the relationships between knowledge leadership and knowledge management were examined, a conceptual evaluation of these relationships was made, and the importance of knowledge leadership both at the organizational level and the school level was emphasized. The study was carried out as a literature review. Following the discussion of the concepts from an organizational point of view, their relationship with the school and the educational environment was addressed. In the study, the concepts of knowledge, knowledge leadership, and knowledge management were explained, and their relationship with each other was described. In addition, based on related literature, the relationship between knowledge management and knowledge leadership was analyzed. It was hypothesized that knowledge leaders had important roles to play in knowledge management processes.

\section{Ethical Procedures}

There is no ethics committee report for the research, as the data in the research is obtained from the documents. However, the study has acted in accordance with research and publication ethics. 


\section{Importance of the Study}

In the literature, it is possible to find studies dealing with the relationship between knowledge management and different leadership styles. However, it is possible to claim that the most appropriate leadership style for knowledge management is knowledge leadership. Definitions supporting this view are presented in the following parts. Studies on the relationship between these two concepts are limited, though. Therefore, the aim of this study was to identify the role of knowledge leaders in knowledge management. This is important in terms of emphasizing the necessity for, and the importance of, knowledge leadership for organizations in general, and schools in particular. Additionally, this study can be considered important in improving the functioning of knowledge management processes, and contributing to the work.

\section{The Concept of Knowledge and its Importance for Organizations}

Before the definition of the concept of knowledge is made, a brief discussion will be presented about the concepts of data and information as they are frequently confused with knowledge and used interchangeably. Data are objective but unrelated, uninterpreted observations and facts about events. Data alone do not have any meaning. They only explain a certain part of the events under consideration and are not reliable in terms of decisions since they do not involve interpretation or evaluation (Karabetyan, 2019). Data can be considered a type of information which has an observable, measurable and calculable value. Information has a more specific framework than data, and includes data, comments, and transactions. In other words, information is data which has been filtered and processed.

On the other hand, knowledge is information created by the combination of experiments, experiences, comments, or ideas. Knowledge is high-value information ready to be applied (Aktan \& Vural, 2016). Briefly, data are "raw facts", information is "organized, shaped data sets", and knowledge is "information that has gained meaning" (Bhatt, 2002, 30-38; as cited in Zaim et al., 2012). In the broadest sense, knowledge refers to the ability to transform data and information into an effective activity. There are various definitions and conceptualizations of knowledge. In related literature, knowledge is anything that is known. Concrete or intangible facts learned as a result of knowing are interpreted as forms of data and the establishment of useful relationships between pieces of knowledge (Memisoglu, 2016). What makes the beneficial relationship established between interpreted data and knowledge pieces meaningful and effective is the sharing of this information. For this purpose, organizations are expected to ensure that individuals cooperate in knowledge sharing and show performance in this regard (Ainissyifa, 2012). Knowledge sharing is the activity of transferring or disseminating knowledge from a person, group or organization, to another person, group or organization (Sönmez Çakır \& Adıgüzel, 2020). When knowledge sharing is considered at the individual level, it can be horizontal and vertical in the organizational hierarchy (Muhammed \& Zaim, 2020). Knowledge is of the greatest value when it is shared. This sharing is necessary both for use and for the solution of future problems and involves obtaining new information by loading it into organizational memory. Sharing information with both employees and service consumers increases efficiency and contributes to the production of new information and solutions (Sakarya, 2006). In other words, data, information and the resulting knowledge sharing within or between 
organizations make it meaningful and effective. In this sense, the issue of what kind of knowledge can be shared occurs to be discussed.

Generally, there are two types of knowledge-explicit knowledge and tacit knowledge. Explicit knowledge is the knowledge expressed in an official language which is recorded and well-documented. It is published and shared as primary and secondary sources of knowledge; it can also be transmitted, transferred, and become available. It can be captured, presented, encoded, and shared. It can be conveyed in a formal and systematic language. On the other hand, tacit knowledge is the knowledge people carry in their minds. It covers personal insights, perceptions, expert opinions, techniques, and skills. Since tacit knowledge is purely personal and specific to a field, it is not transmitted into writing and can only be shared verbally. Tacit knowledge is personal and context-specific, and therefore is difficult to formalize and convey. This knowledge is very useful, but it is concealed by the individual and is not easily transmitted (Dhamdhere, 2015). The transfer of tacit knowledge is based on transparent and reliable relationships. Trust is critical when different groups who believe in the power of knowledge come together to share or create knowledge (Williams, 2012). Transferring tacit knowledge is extremely important for the survival of the organization (Sprinkle \& Urick, 2018). Studies show a positive relationship between implicit knowledge and both corporate and individual performance (Zaim et al., 2012). Explicit knowledge can be easily shared among everyone in the organization. The most difficult form of knowledge management is the management of tacit knowledge. Tacit knowledge can be considered as intuitive knowledge guided by experience. The core of the concept of knowledge management is to help individuals to be in contact with each other to share tacit knowledge or to transform the tacit knowledge into explicit knowledge which can be used by the whole organization (Chinowsky \& Carrillo, 2007). Orphan knowledge is not lost in the organization; instead, it is the knowledge that is forgotten, ignored or neglected, and not used within an organization. Orphan knowledge differs from tacit knowledge in that sense. People are aware of the tacit knowledge, while they are not aware of the existence of orphan knowledge (Durna \& Demirel, 2008).

Therefore, a sound knowledge management system should handle all kinds of knowledge, both tacit and explicit. This is the biggest requirement and challenge when it comes to implementing a knowledge management process (Chu et al., 2011). Studies show that transferring knowledge in face-to-face meetings can produce more effective results, and mutual knowledge transfer can guarantee its applicability (Kaiser et al., 2016). Schools are one of the organizations where knowledge transfer is most common through face-to-face interaction. This is because, in a school, knowledge is shared through person-to-person interaction, often based on conversations between professional groups in social networks rather than through the use of information technology. In other words, teachers' communication and knowledge sharing with their colleagues, the coding of their teaching information in documents, is usually carried out on a person-to-person basis rather than through the school intranet (Cheng et al., 2017).

Knowledge and learning are moving factors for business success and competitiveness, especially in knowledge-intensive organizations whose main service is to create and sell knowledge (Mas-Machuca, 2014). Educational institutions are knowledge-intensive organizations. In daily educational activities, schools must acquire, 
store, share, use and produce information. In other words, they should be able to manage knowledge in order to educate their students effectively (Özmen, 2010). As information and knowledge have become an important productivity factor for the modern school system, society will inevitably demand the intensive management of information and knowledge. Therefore, how to manage knowledge will become an important issue for schools soon (Kurnıawan, 2014). Schools -especially teachers- are known as not generous in terms of sharing knowledge, although they are involved in the learning process. There are established structural and normative reasons for this situation that schools have acquired as part of their historical and evolutionary process. Due to their work, teachers have little time to get together throughout the day to share their ideas and improve their teaching. Most of the time, teachers do not tend to give and receive information. Indeed, in many cases, school cultures discourage information sharing because of some common beliefs such as "Who does s/he think s/he is? Others won't be interested in what I'm doing" (Fullan, 2002). However, in a climate of increased external and internal pressures, the need for the knowledge of teachers and administrators has never been so great, but it is a fact that there are dangers of excessive knowledge overload. Schools, like most organizations, must acquire knowledge to increase teacher competence. Therefore, there are many types of information that need to be managed in schools (Chu et al., 2011).

Knowledge and leadership in modern business are the two most valuable resources of an organization. A leader's behavior, values, attitudes, characteristics, skills, and abilities greatly affect the creation of organizational knowledge. A leader has an important role in creating an environment that encourages individual and team learning. A leader should support and encourage a culture of creating, sharing, using, promoting, and acquiring new knowledge in organizations, that is, s/he should be involved in organizational knowledge management. In brief, a leader has a crucial role in organizational knowledge management (Micić, 2015). This means that leaders must manage knowledge.

\section{Knowledge Management, its Purpose and Benefits}

Knowledge management is closely related to many disciplines such as psychology and economics and is the ultimate advantage in today's organizations. Knowledge management has a very positive effect on organizational processes. The aim is to capture knowledge and enable employees, as knowledge managers, to share this information. If a manager can capture and spread knowledge within the organization, the benefits s/he will gain are quite high (Akyazıc1, 2019). Knowledge management is thought to be a concept that can provide a competitive advantage, primarily for commercial organizations. However, knowledge management processes such as creating, capturing, sharing, and using knowledge are not specific to business environments. Good knowledge management practices can benefit all organizations. One type of such organizations is knowledge-intensive schools (Muratoğlu, 2005). Although knowledge management is an area that has been growing in the last two decades, little has been written about it in the context of education. This is surprising as education is all about the creation and application of knowledge (Ibrahim \& Salleh, 2019). 
Knowledge management can be considered the process of transforming data and information into knowledge and then disseminating it within the organization (Lakshman, 2009). Knowledge management is the organization of an organization's knowledge through a systematic and organization-specific process which includes refreshing, sharing, applying, maintaining, organizing, and obtaining the tacit or explicit knowledge of employees in such a way that it will be possible to create value and increase organizational performance (Allee, 1997; as cited in Montgomery, 2012). Knowledge management processes include the acquisition, creation, refinement, storage, transfer, sharing, and use of information. The function of knowledge management in organizations is to run these processes, develop systems and methods to support them, and motivate people to participate in them (King, 2009; Kurniawan, 2014). It is inevitable to use information technologies in the process of knowledge management because the conveniences technology brought have revolutionized the lowcost and fast storage, share and production of knowledge in organizations. However, technology alone is not sufficient enough for knowledge management practices in organizations, and it is a necessity for effective knowledge management (Özdemirci \& Aydın, 2007). Knowledge management in different organizations can serve different organizational purposes. For example, some organizations focus on customer knowledge; some deal with knowledge capital, the others might be concerned with providing enhanced access to knowledge (Rowley, 2000). Since the knowledge management process in secondary education and higher education will operate at different levels and in different qualities, the objectives may also differ. However, the common point at all levels is that the organization aims to achieve its goals, maintain its competitive power, and make its performance effective. In summary, it is possible to state that leadership roles, leadership types, leadership abilities, and demographic characteristics can affect leadership roles in knowledge management (Doğan \& Kılıç, 2009).

The purpose of knowledge management is to improve the quality of people's contributions to their organization, to negotiate effectively, and to learn from others by helping people understand the context of the organization, take responsibility, cooperate, and share what they know and learn (Chu et al., 2011). The objectives of knowledge management are the development and exploitation of the organization's information assets for the realization of better information activities, improved organizational behavior, better decisions, and improved corporate performance (King, 2009). The benefits of knowledge management are evaluated in terms of the efficient use of information, storing intellectual capital, enhancing activities, strategic planning, improving organizational memory, gaining flexibility, gathering best practices, enhancing the likelihood of success, and efficient cooperation between organizations. The greatest benefit of knowledge management is that knowledge is easily shared among staff and that information is not lost if someone goes on vacation, becomes ill, or leaves the organization (Martin 2003; as cited in Mohajan, 2017).

Knowledge management is based on the premise that, just as people cannot use the full potential of their brains, organizations cannot use all the information they have. Through knowledge management, organizations try to create or obtain useful knowledge and make it available to those who can use it in the right place and at the right time to affect corporate performance. It is believed that an organization will gain 
great benefits if its effective use of knowledge can be increased (King, 2009). Effective knowledge management requires new roles and responsibilities for both managers and employees. It is a continuous social process in managing the organization's knowledge assets, clarifying the objectives in the event of uncertainty, encouraging mutual learning and continuous skill development, and developing trust between stakeholders, both inside and outside the organization. Employees who take responsibility for making and creating meaning need to understand and discuss their work. They need to look at their work from different perspectives and encourage and invite critical thinking (Carroll et al., 2003).

Knowledge management is being newly experienced in schools. Schools that take the initiative to share knowledge to achieve their goals ascertain that it offers excellent value. The aim is to use knowledge management within the school and facilitate a knowledge-based system for academic purposes (Kurniawan, 2014). Schools, like most organizations, must acquire knowledge to improve decision-making and innovation, especially in an age of increasing internal and external pressure for change and improvement. Schools can use knowledge management as a strategy to improve their competitive performance (Chu et al., 2011). Knowledge management helps educational institutes improve their capacity to obtain and share information and knowledge and apply these to problem-solving and support the research and continual improvement of their work. Knowledge management of the educational system must reflect and include information at all levels starting from management level to student level, to improve employees' professional knowledge and achieve quality of lecturers and students (Dhamdhere, 2015). Schools are the places where knowledge is mostly known, used and new information is produced.

For this reason, knowledge management can easily be conducted at schools. It is necessary for a school executive to be interested in knowledge and aim at a knowledgebased administration. The same is valid for teachers as they are the ones who will accomplish this process. Both executors and teachers should become the people who continuously search, learn, and follow the knowledge changing constantly. Knowledge management process in a school should be supported with technology and computer, and sufficient number of computers and Internet networks should be available (Güçlü \& Sotırofsk1, 2006). Studies have shown that knowledge management practices have a positive and significant effect on improving the quality of high schools (Ainissyifa, 2012). Knowledge management can be used as an alternative strategy by schools to help them face the challenges of improving performance in a similar way that it is used in commercial sectors. However, little research has been done on how knowledge management can be applied to the school environment. It is very important to understand the knowledge management perceptions of teachers when it comes to implementing knowledge management (Chu et al., 2011). Knowledge management for schools has the potential to encourage the sharing of innovative practices, avoid duplication, and prevent the loss of valuable knowledge (Thambi \& O'Toole, 2012). Knowledge management initiatives in teaching and learning can be used as part of a corporate strategy to create, transform, store, and disseminate knowledge according to students' needs (Ibrahim \& Salleh, 2019). 


\section{Leadership Roles in Knowledge Management}

Leadership plays an important role in value creation, innovation, knowledge management, and implementation strategies (Besen et al., 2017). The way leaders behave and act shows what is expected and how things will be done because members of the organization are attentive to their behaviors and constantly observe the actions of their leaders (Edmondson, 2004; as cited in Carmeli \& Sheaffer, 2008). The power of leaders and the influence of their ideas can be seen in their ability to motivate and inspire their followers to accept change, constantly gain knowledge, and share with other organization members (Micić, 2015). Knowledge management leadership covers how leadership practices define the work of the organization, determines how it uses information assets to strengthen its core competencies and implement broad strategy issues. Leaders should encourage the use of knowledge for the benefit of the whole organization rather than for individual advantage. The aim should be to create an environment of information sharing that requires a change in employees' mentality. For this reason, the impact of senior managers' cognitive styles on knowledge management practices is important (Jain \& Jeppesen, 2013).

With regard to knowledge management at the organizational level, a knowledgefriendly knowledge management culture within the organization is one of the critical elements of success. Management plays a major role in creating a culture that enables knowledge management. Managers and leaders should actively encourage the creation and use of knowledge. Leaders should maintain and store records, develop a sense of common direction, enthusiasm for learning and mutual trust, and encourage cooperation and healthy competition (Stylianou \& Savva, 2016). The organizational culture and leadership behavior of the school affect knowledge management. It is necessary for knowledge management to demonstrate leadership behavior according to the school's organizational culture. The success of a school administrator in terms of information management can be enhanced by a good analysis of the dynamic sociological structure of the school (Özgözgü \& Atılgan, 2017). Organizational culture is extremely important for the success of knowledge management. Employees' willingness to learn, being intellectually superior, being encouraged by managers to create and use knowledge, blocking processes that prevent employees from sharing knowledge, and employees' positive orientation towards knowledge, are all determinants concerning the organizational culture being a supportive factor in knowledge management. Knowledge sharing in the organization should be encouraged and rewarded (Aktan \& Vural, 2016). Leaders play a vital role in creating and maintaining an organizational learning culture (Stonehouse \& Pemberton, 1999; as cited in Crawford, 2005).

As individuals are an integral part of knowledge management practices (such as knowledge creation, sharing, and storage), there are studies examining the role of leadership in influencing and promoting employees' behavior in this direction. For instance, in a study conducted by Johnson (2002), during which four leaders who want to transform their organizations into learning organizations were interviewed, it was concluded that leaders who wanted to be successful in promoting knowledge management practices should include employees at all levels of the organization. However, it is not clear yet which leadership style is the most suitable for conducting knowledge management activities (as cited in Analoui et al., 2013). A smart organization is an organization believed to have significantly different leadership styles 
applied to achieving pre-determined goals. The most important task of leaders in such organizations is to encourage knowledge sharing by supporting learning and providing continuous group learning (Macneil 2001; as cited in Singh, 2011). Leadership roles include promoting an organizational learning culture, encouraging information sharing, determining the knowledge management strategy and vision, encouraging employees to share information, supporting knowledge management activities, learning from experiences, and adopting a reward system with regard to the implementation of knowledge management (Doğan \& Kilıç, 2009). In addition, leaders must create a special culture for knowledge sharing based on values such as trust, transparency, and honesty. These values will improve the sense of belonging to the institution and increase the ability to learn and internalize new practices (Mas-Machuca, 2014). Research studies reveal that a manager's leadership support is an important factor that contributes to knowledge share among coworkers. Knowledge share among coworkers and managers' leadership support has a positive impact on the organizations' success of knowledge management, which may positively influence organizations' innovation performances (Muhammed \& Zaim, 2020).

\section{Knowledge Leadership}

Some research studies reveal that leadership is a necessary element in knowledge management processes (Balkar, 2012; Demirel \& Seçkin, 2008). The knowledge leader is the person who establishes and supports the systems that ensure the formation of a knowledge sharing culture within the organization, establish the infrastructure that facilitates the transfer and storage of knowledge, and enables mutual learning within the organization (Dfoinı \& Croteau, 2003; as cited in Doğan \& Kiliç, 2009). Knowledge leadership is defined as a process by which the individual supports other group members in the learning processes required to achieve group or organization goals (Stogdill, 1974; as cited in Yang et al., 2014). The role of knowledge leadership is to foster a positive cultural orientation that values continuous learning, experience, and expertise, and innovation that replaces hierarchy, in line with knowledge acquisition and knowledge sharing (Davenport et al., 1998; as cited in Yang et al., 2014). The role of the knowledge leader is to provide strategic vision, motivate others, communicate effectively, act as a change agent, coach others, model good practices, and implement the information agenda (Debowski, 2006; as cited in Singh, 2011). Knowledge leaders are the leaders who plan and direct organizations' performances regarding knowledge management and encourages the attainment of new experiences from the conclusions derived from the systematic analysis of the results. Knowledge leaders should take the support of top-management and continuously motivate their employees about the practices of knowledge management in order to play their expected roles effectively. It is essential for knowledge leaders to provide needed support from the bottom to the top in order to encourage the flexibility and readiness at the organizational level (Y1lmaz, 2014). Knowledge leaders need to have various interpersonal and organizational development skills to ensure cultural change, establish relationships and facilitate knowledge transfer (Ali \& Yusof, 2006; as cited in Yang et al., 2014). Knowledge leaders are responsible for all the components of the organization, and the areas where organizational knowledge competence needs to be improved, while adhering to the mission and vision of the organization. They have 
important responsibilities in terms of realizing difficult processes such as meeting the knowledge sharing needs among units (Doğan \& K1lıç, 2009). It is possible to discuss the competencies and roles that the leader should have in carrying out these responsibilities. Viitala (2004) addressed these roles and competencies in four dimensions (Daryono et al., 2015): 1-Learning orientation, that is, leaders to guide learning and help others to understand the purpose of learning 2-Learning climate, that is, encouraging trust, showing a proactive and positive attitude towards mistakes and failures, accepting criticism and trying to develop a favorable social environment in the work unit 3-Learning support, that is, the leaders being available to analyze, plan and create a portfolio of competencies and the learning processes of all employees 4-Role model, that is, leaders act as role models (Figure 1).

Figure 1

Basic Dimensions of Knowledge Leadership

Being a direction determinant in learning

Creating a climate that supports learning

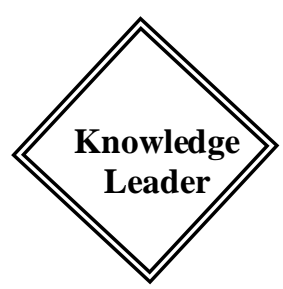

Supporting group or individual learning processes

Being a role model

Publication (Viitala, 2004).

As seen in Figure 1, the basic dimensions of knowledge leadership are gathered together in four areas. First, a knowledge leader is primarily a person who should be a role model in the eyes of employees. Determining the direction of the learning process is the second important function of a leader. Third, the leader plays a role in knowledge leadership by creating a supportive learning climate, and supporting group and individual learning processes. Fourth, as a requirement of the knowledge society, managers must possess the qualifications driven from the source of their authority in knowledge (Şahin, 2010).

\section{Management \\ The Role and Importance of Knowledge Leadership in Knowledge}

Knowledge management is one of the important needs of organizations to give effective decisions, work effectively, create an innovative environment with highly motivated employees, and ensure continuous development and knowledge sharing in such an environment. Leaders/managers have a great role in fulfilling these needs. Leaders can create a culture that enables knowledge sharing among employees and contributes to the use of knowledge in organizational decision-making processes 
(Doğan \& Kılıç, 2009). However, since it is difficult to ensure that knowledge management is continuous, it entails an important leadership responsibility (Baker in Myers, 1996; as cited in Lakshman, 2007).

In the knowledge management process, leadership can be accepted as a process in which other group members are supported in the learning processes so that the group will achieve its goals or the organization's goals. In this process, the leader's primary task is to activate the knowledge assets of the organization so that all benefit from this knowledge. Organizations can be successful in knowledge management if leaders/managers adapt to change and have leadership characteristics (Doğan \& Kıliç, 2009). Leadership in the knowledge management process can be defined as a process by which members of the group are individually supported in the learning processes required to achieve the goals of the group or the organization (Bozdoğan, 2013). According to Klenke (1994), leaders play a vital role in the construction and maintenance of organizational knowledge. They need to place a high value on knowledge, empower employees, encourage inquiry, build trust, and facilitate the experiential learning of tacit knowledge (Stonehouse \& Pemberton, 1999; as cited in Allameh et al., 2012). The incompetencies of leaders cause insufficient knowledge management due to their inability to execute knowledge management (Sandström et al., 2017).

Various factors contribute to the successful execution of knowledge management, and good leadership is a key determinant among these factors. An organizational culture that is key to knowledge management, emphasizing collaboration, sharing, and innovation, can only be built under the strong leadership and commitment of top management, which can positively affect an organization's knowledge-sharing efforts. Since decision-making is knowledge-intensive, knowledge management facilitates information and sustains decision-making (Jain, 2015). Therefore, leadership has a positive relationship with the success of knowledge management. It is possible to observe this relationship in an organization where senior management provides support and some incentives for information sharing, and where the knowledge management project is a part of the corporate strategic plan. In short, the leader plays an important role in the knowledge management process. To be successful, the leader must own the qualities and skills to create, share, and use information within the organization. However, apart from the creation, transfer, and use of knowledge, it is also important for the leader to encourage and create new knowledge to create value for the organization (Micić, 2015). The management of knowledge represents more than the process that begins with the creation of knowledge, continues with the sharing of such knowledge throughout the organization, and ends with using the knowledge. There can be no effective knowledge management without effective leadership. Therefore, the person who needs to create the conditions for creating, sharing, using, and acquiring new knowledge in organizations is the leader (Micić, 2015). In particular, it is thought that leaders should value knowledge, encourage inquiry and experience, build trust, and ensure that tacit knowledge is transferred into practice (Stonehouse \& Pemberton, 1999; as cited in Crawford, 2005). Leaders must provide the mission, vision, systems, and structures that will facilitate the transformation of knowledge into competitive advantages at all levels of the organization (Conger \& Kanungo, 1998; as cited in Allameh et al., 2012). 
Davenport and Prusak (1998) suggest some specific advice to future leaders regarding their role in knowledge management. Their suggestions can be listed as (cited in Crawford, 2005):

Maintain the importance of knowledge and learning in the organization,

Design, implement and supervise the learning infrastructure of the organization,

Manage relationships with external information providers,

Produce ideas that will improve the knowledge creation process in the organization,

Design and implement a knowledge coding approach,

Measure and manage the value of knowledge,

Lead the development of learning and knowledge strategies by focusing on organizational resources.

Figure 2 summarizes the role of leaders in terms of knowledge management. First, the leader should realize the importance of knowledge management. Second, the leader both implements and directs knowledge management and participates in this process personally. This affects organizational performance and leadership perceptions. If the leader uses customer-oriented knowledge management (with the help of sociocognitive networks and technological networks) in parallel with realizing the importance of knowledge management, it will ultimately have an impact on organizational performance and leader perceptions.

Figure 2

The Role of Executive Leadership in Knowledge Management

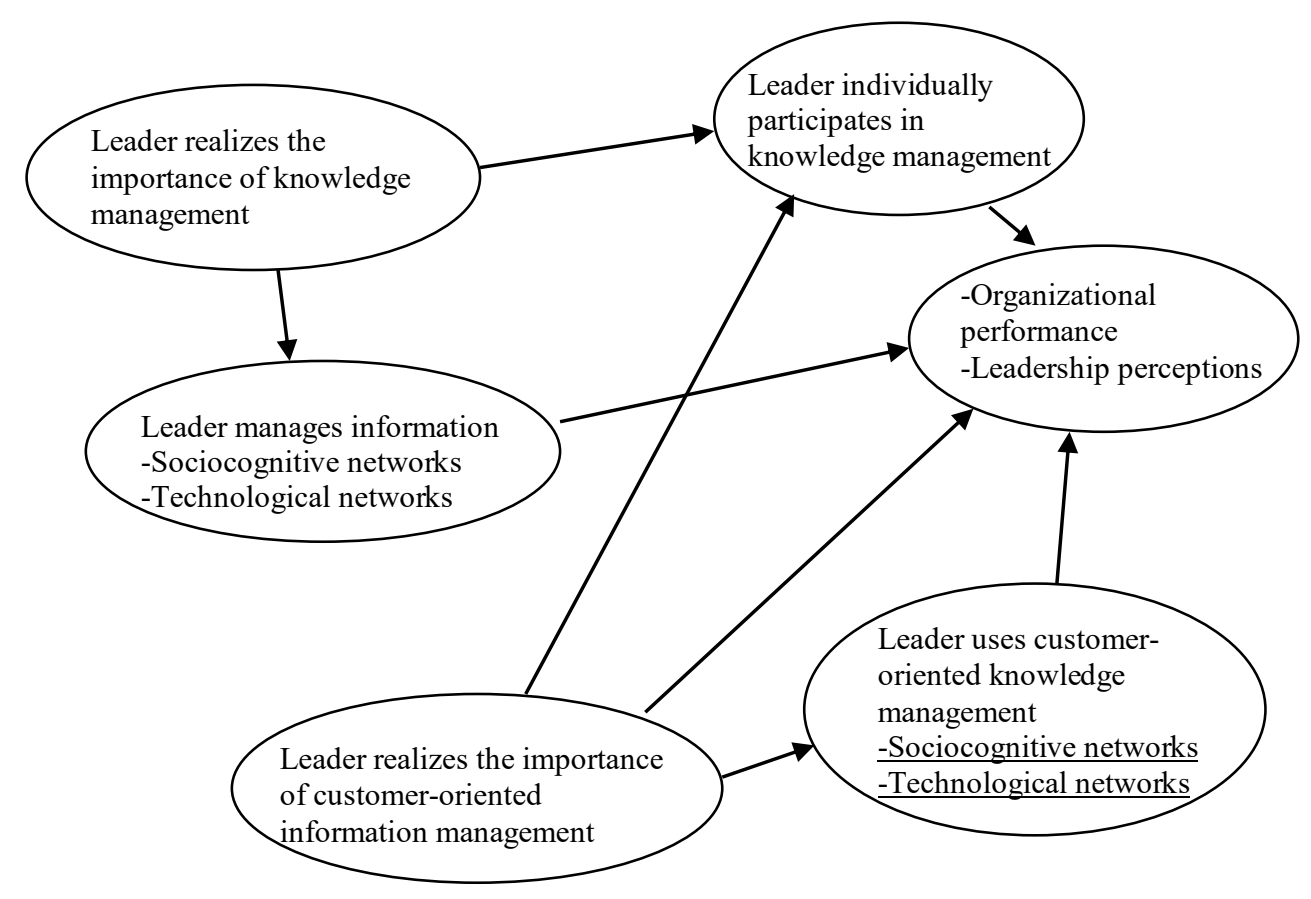

Publication (Lakshman, 2007).

Leadership support strongly influences the users' knowledge-seeking behavior through knowledge management systems. Consequently, knowledge sharing increases 
within the organization. Studies show that leaders play an important role in the success of knowledge management systems and that leader's support and behavior motivate employees to share information (as cited in Humayun \& Gang, 2013). In summary, many knowledge management researchers have identified leadership as an important variable in the relationship between knowledge management and organizational effectiveness (Bell De Tienne, 2004; as cited in Lakshman, 2007). The learning process has the potential to become crucial in the implementation of knowledge management.

For this reason, school administrators should encourage and facilitate the learning process on the part of educators to enable individuals to collaborate and perform by sharing the most appropriate knowledge. School administrators should complement the school environment and the characters involved in the formation of a learning school, and at the same time, provide solutions to overcoming the learning barriers faced by the organization (Ainissyifa, 2012). In his study on leadership and knowledge management skills, Balkar (2012) found a moderate, positive, and significant relationship between the knowledge management process competencies of secondary school principals and their leadership skills. The study revealed that the leadership skills of school principals were a significant predictor of knowledge management process competencies. Karakoç (2010), on the other hand, stated that the transformational leadership characteristics of school principals reflected positively on knowledge management processes. It was found out that the relationship between transformational leadership traits and knowledge management processes was significantly higher than interactional leadership traits. According to the opinions of teachers and school principals who took part in his study, Şahin (2010) stated that there was a highly significant relationship between principals' knowledge management skills and schools being learning organizations. It was concluded that principals' knowledge management skills were a significant predictor of the learning organization level of schools.

The relationship between leadership and knowledge management has been discussed in this section. Studies on explaining the importance of leadership roles in knowledge management with knowledge leadership, which is a more specific type of leadership, indicate the relationship between the processes of transferring, storing, and applying knowledge in terms of knowledge management and knowledge-oriented leadership (Donate \& Pablo, 2015; Lakshman, 2007). The knowledge leader should be an advocate of knowledge and learning. The knowledge leader is the designer, implementer, and supervisor of knowledge infrastructure, including libraries, knowledge bases, human resources, computer information networks, research centers, and the academic relations of an institution (Davenport 1994; as cited in Kok, 2003). Obtaining the desired benefit from knowledge management can be achieved by creating a structure for knowledge leadership in the organization (Bozdoğan, 2013). Interpersonal communication skills, emotional maturity, enthusiasm, and the ability to build both internal and external networks, are important knowledge management skills needed by knowledge leaders (Kok, 2003). Knowledge leaders need to explain the goals of knowledge management to determine their roles in achieving these goals. In other words, knowledge leaders need to guide the processes necessary to achieve the desired goals (Debowski, 2006; as cited in Singh, 2011). Knowledge leadership, knowledgesharing culture, and knowledge management system support are the elements of success 
in schools' knowledge management practices (Cheng et al., 2017). The knowledge leader has a great responsibility to educate his/her employees in knowledge management and highlighting its benefits. These responsibilities include defining employees' roles, skill sets, and career opportunities, developing a strategy that will facilitate education and training, and developing learning centers (Kok, 2003). Knowledge leadership promotes organizational learning (Chou \& Ramser, 2019). Knowledge leaders must possess the characteristics of contemporary knowledge leadership (Bozdoğan, 2013).

A knowledge leader should strategically integrate information into the organization by following the stages presented below (López, 2013):

a) Defining Identity: The knowledge leader should define the identity of the organization in order to understand the principles of the organization's activities and products.

b) Finding the Knowledge Needs: The next step in organizational identity is to identify the knowledge needs of the institution and the key actors that will allow the organization to meet these needs.

c) Designing the Knowledge Strategy: The knowledge leader produces the strategy to be followed by the organization with the knowledge previously gathered. The knowledge strategy must be in line with the organizational strategy. Therefore, elements such as identity and knowledge needs should be considered for its design.

d) Motivating the Transfer of Knowledge: Knowledge leaders should use tools to encourage motivation among organization members so that they can agree to transfer the knowledge they have. This is useful for organizational processes.

e) Constructing the Knowledge System: After the staff has become motivated to follow the knowledge strategy, the knowledge system will be built. This will include the technological aspects and the administrative and normative processes that make up the knowledge system.

In summary, it is possible to state that knowledge leaders are one of the main actors for organizations in terms of knowledge management processes. Determining the existing organizational knowledge level, fulfilling the organizational responsibilities in the process of creating and obtaining knowledge, creating an environment and culture that will facilitate the knowledge sharing of the employees, and ensuring the storage of the knowledge used, will only be possible with the existence of knowledge leaders (Doğan \& Kılıç, 2009). The purpose of information management is to inform the organization on time about the scientific and technological developments occurring in the environment of the organization, and to reflect this to the organization. It is of great importance that schools, which are organizations that produce and distribute information, be aware of these developments (Sakarya, 2006). This is because knowledge management supports the aims of education and increases the effectiveness of learning. School administrators' being active in the processes of obtaining, sharing, using, and storing information contributes significantly to the achievement of the goals of schools (Özsarıkamış, 2009). School leaders and employees need to come up with effective strategies to achieve the desired level in knowledge management (Muratoğlu, 2005). 


\section{Discussion and Conclusion}

Technological developments in the last century have significantly affected the management of organizations. In particular, the subject of knowledge management has started to play an important role in providing competitive advantages for organizations. Therefore, schools, which are knowledge-based organizations, should develop knowledge management strategies to provide an effective education that meets the needs of the age. In this context, the school principal is of great importance as this individual is considered the leading authority for achieving educational goals (Özmen \& Muratoglu, 2010). Due to the multitude of internal and external stakeholders associated with schools, school principals should ensure social participation in knowledge management practices. They may face difficulties in gaining support and voluntary participation in the operation of the process. This situation requires school principals to be competent in terms of both knowledge management and leadership skills (Balkar \& Şahin, 2012). Knowledge leaders are needed at all levels of the organization. To achieve the organization's goals, knowledge leaders must balance the creation and use of knowledge to increase both their professional effectiveness and the organization's effectiveness. Even if such a leader is not necessarily a manager of the organization, a knowledge leader needs to be functional, adaptable, sustainable, and offer timely intervention. It is important to emphasize that leaders have to focus on tasks or relationships. Since these traits are frequently difficult to find in one person, ideally, leadership in an organization should involve a team. In other words, there should be more than a single knowledge leader (López, 2013). This means that everyone should have the appropriate competencies and be active in the knowledge leadership role. Such a situation will both alleviate the burden on school principals and have consequences that can be attributed to the whole organization through shared knowledge leadership. Thus, the advantages of knowledge for the school will become more evident through effective knowledge leadership. School principals can be determinant in ensuring this, because teachers and other staff members often expect leaders to have an expected behavioral pattern and ability to encourage the achievement of the desired goals. If this leadership ability is used for the benefit of the development of knowledge management systems, they encourage the search for knowledge through such systems (Al-Ani \& David, 2009; Wei \& Kwok-Kee, 2009; as cited in Humayun \& Gang, 2013).

Consequently, every employee becomes motivated to be a knowledge leader by demonstrating the expected behavior patterns. Educational research shows that it is considered separately. Most school variables have only a small effect on learning. The real effect occurs when these individual variables combine to achieve critical mass. It is up to the principal to create the conditions under which this can happen (The Wallace Foundation, 2013). In other words, the synergy arising from a combination of the power of each part of the system can enable the effectiveness of all the variables relating to the school. This makes it easier for the school to achieve its goals. One of these sub-systems within a school is a school principal who has taken on the role of knowledge leadership, and another is teachers who share this role.

The ultimate goal of the organizational learning process is to form a learning organization. For this reason, knowledge management is extremely important in providing information that will constitute a basis for learning. Learning organizations create unique knowledge by internalizing the information they obtain, and use it in their 
organizational behavior. The change and development in organizational behavior is an indicator of organizational learning. Therefore, knowledge management processes come into play in the realization of organizational learning (Üzüm, 2009). In learning organizations, all employees constantly pursue knowledge and learn to learn. The aim of learning is to encourage change and ensure development and innovation (Şahin, 2010). In the light of all these explanations, it can be inferred that the concepts of organizational learning and knowledge management are closely related. Knowledge management is the pioneer of organizational learning, the engine of organizational affairs, and a powerful and indispensable learning organization tool (Dahou et al., 2019). The person who can manage all these processes in an organization is a knowledge leader, or a shared knowledge leadership culture in the organization can do it. It can be seen that these concepts are based on the concepts of learning and knowledge. Therefore, the importance given to knowledge and learning, and the severity of the need for these concepts are the basic conditions that will ensure that these concepts are on the agenda of organizations. As previously stated in this study that knowledge leadership is necessary, in contrast to those approaches (López, 2013) which state that a very consolidated form of knowledge leadership is required despite the need for cooperation to create and transfer information within organizations. In addition, researchers have tried to emphasize that there is a responsibility that all employees should undertake with a shared leadership understanding.

The centralistic structure of the Turkish Education System and the nature of leadership can be seen as obstacles for school principals to play different leadership roles (Bursalığlu, 1999; Gümüşeli, 1996). However, there should be no obstacle to being a knowledge leader. Being a knowledge leader is only possible by feeling the need for knowledge and establishing processes and structures that will transfer this feeling to school staff. Knowledge leaders first access and use knowledge themselves, and both demonstrate and spread the power of such knowledge. Thus, they can be more effective among employees. Knowledge leaders must have the power of knowledge and the capacity to use that knowledge so that this will fascinate employees. Knowledge leaders are indispensable actors in the knowledge management process. In addition to the knowledge management process, knowledge leaders play a great role in making learning an indispensable habit on the part of the organization. The most important task of knowledge leaders is to be able to benefit from knowledge by activating the knowledge assets of the organization. The knowledge leader has important effects on the creation, processing, sharing and storage of knowledge, and making learning part of an organizational culture. This is necessary because knowledge management will not occur spontaneously and will not develop without constant human intervention. The appointment of a knowledge leader is an acknowledgment of the importance of knowledge in the future well-being of an organization (Kok, 2003). Schools are knowledge-intensive organizations, and there are many areas of knowledge that need to be managed. The main actors in managing this knowledge are school principals. Therefore, knowledge management and leadership skills can be considered important qualities that school principals should have. 


\section{Implications}

This study offers a discussion at the conceptual level. Applied research on the relationship between knowledge leadership and knowledge management can be done. In addition, the opinions available in the literature show that the stages in knowledge management processes require different leadership styles. Knowledge leadership roles are a responsibility that should be taken into account by all employees within an organization and can be examined through research using different research designs and approaches.

\section{Conflicts of Interest}

There are no conflicts of interest in this study.

\section{References}

Ainissyifa, H. (2012). The influence of knowledge management implementation toward the quality of high schools. International Journal of Development and Sustainability, 1(2), 79-84.

Aktan, C. C., \& Vural, İ. (2016). Bilgi çağında bilginin yönetimi. Yeni Türkiye, Bilim ve Teknoloji Özel Sayısı, 88(1), 1-15.

Akyazıcı, M. (2019). Bilgi yönetimi (Yayımlanmamış yüksek lisans tezi). Bahçeşehir Üniversitesi, İstanbul.

Allameh, S. M., Babaei, R. A., Chitsaz, A., \& Gharibpoor, M. (2012). The study of relationship between leadership styles (Transformational/Transactional) and knowledge conversion processes among faculty members in university. Australian Journal of Basic and Applied Sciences, 6(7), 46-54.

Analoui, B. D., Doloriert, C. H., \& Sambrook, S. (2013). Leadership and knowledge management in UK ICT organisations. Journal of Management Development, 32(1), 4-17. https://doi.org/10.1108/02621711311286892

Balkar, B. (2012). Ortaöğretim okulu müdürlerinin liderlik becerilerinin bilgi yönetimi süreç yeterliklerindeki rolü (Yayımlanmamış doktora tezi). Gaziantep Üniversitesi, Gaziantep.

Balkar, B., \& Şahin, S. (2012). Okul müdürlerinin bilgi yönetimi süreç yeterliklerinin ve liderlik becerilerinin incelenmesi. Ĕ̌itim ve Öğretim Araştırmaları Dergisi, l(2), 178-188.

Besen, F., Tecchio, E., \& Fialho, F. A. P. (2017). Authentic leadership and knowledge management. Gest. Prod., São Carlos, 24(1), 2-14. http://dx.doi.org/10.1590/0104530X898-13

Bozdoğan, T. (2013). A research on knowledge leadership characteristics in accounting department managers in Turkey. International Journal of Business and Social Science, 4(14), 125-136.

Bursalığlu, Z. (1999). Okul yönetiminde yeni yapı ve davranış (11. baskı). Pegem.

Carmeli, A., \& Sheaffer, Z. (2008). How learning leadership and organizational learning from failures enhance perceived organizational capacity to adapt to the task environment. The Journal of Applied Behavioral Science, 44(4), 468-489. http://dx.doi.org/10.1177/0021886308323822 
Carroll, J. M., Choo, C. W., Dunlap, D. R., Isenhour, P. L., Kerr, S. T., MacLean, A., \& Rosson, M. B. (2003). Knowledge management support for teachers. Educational Technology Research and Development, 51(4), 42-64.

Cheng, E. C. K., Wu, S. W., \& Hu, J. (2017). Knowledge management implementation in the school context: case studies on knowledge leadership, storytelling, and taxonomy. Educ Res Policy Prac, 16, 177-188. http://dx.doi.org/10.1007/s10671016-9200-0

Chinowsky, P., \& Carrillo, P. (2007). Knowledge management to learning organization connection. Journal of Management in Engineering, 23(3). 122-130.

Chou, S. Y., \& Ramser, C. (2019). A multilevel model of organizational learning Incorporating employee spontaneous workplace behaviors, leadership capital and knowledge management. The Learning Organization, 26(2), 132-145. http://dx.doi.org/10.1108/TLO-10-2018-0168

Chu, K. W., Wang, M., \& Yuen, A. H. K. (2011). Implementing knowledge management in school environment: Teachers' perception. Knowledge Management \& E-Learning: An International Journal, 3(2), 139-152.

Crawford, C. B. (2005). Effects of transformational leadership and organizational position on knowledge management. Journal of Knowledge Management, 9(6), 616.

Dahou, K., Hacini, I., \& Burgoyne, J. (2019). Knowledge management as a critical success factor in developing international companies' organizational learning capability. Journal of Workplace Learning, 31(1), 2-16. https://doi.org/10.1108/JWL-12-2017-0118

Daryono, M., Nimran, U., Suhadak, \& Rahardjo, K. (2015). The effect of knowledge leadership toward organizational culture, Individual learning, and collective learning and its implication toward individual creativity: a study on state owned plantation enterprises of Indonesia. European Journal of Business and Management, 7(6), 192-204.

Demirel, Y., \& Seçkin, Z. (2008). Bilgi yönetimi uygulamasında etkili olan faktörler üzerine mobilyacılık sektöründe bir araştırma. Zonguldak Karaelmas Üniversitesi Sosyal Bilimler Dergisi, 4(8), 107-122.

Dhamdhere, S. N. (2015). Importance of knowledge management in the higher educational institutes. Turkish Online Journal of Distance Education-TOJDE, 16(1), 162-183. https://doi.org/10.17718/tojde.34392

Doğan, S., \& Kılıç, S. (2009). Bilgi yönetiminde liderliğin rolü: Kapadokya bölgesinde faaliyet gösteren KOBI'lerde bir araştırma. “IŞ, GÜÇ”” Endüstri Ilişkileri ve İnsan Kaynakları Dergisi, 11(3), 29-50.

Donate, M. J., \& Pablo, J. D. S. (2015). The role of knowledge-oriented leadership in knowledge management practices and innovation. Journal of Business Research, 68(2), 360-370. https://doi.org/10.1016/j.jbusres.2014.06.022

Durna, U., \& Demirel, Y. (2008). Bilgi yönetiminde bilgiyi anlamak. Erciyes Üniversitesi İktisadi ve İdari Bilimler Fakültesi Dergisi, 30, 129-156.

Fullan, M. (2002). The role of leadership in the promotion of knowledge management in schools. OECD Conference, March 18-19, 1-19. 
Güçlü, N., \& Sotırofskı, K. (2006). Bilgi yönetimi. Türk Eğitim Bilimleri Dergisi, 4(4), 351-371.

Gümüşeli, A. İ. (1996). Okul müdürlerinin öğretim liderliğini sınırlayan etkenler. Ĕ̈itim Yönetimi, 2(2), 1-9.

Humayun, M., \& Gang, C. (2013). Impact of leadership support on kms-based knowledge seeking behavior: lessons learned. Research Journal of Applied Sciences, Engineering and Technology, 5(1), 218-223.

Ibrahim, F., \& Salleh, N. M. (2019). Embedding knowledge management theory in learning and teaching approach. International Journal of Learning and Development, 9(1), 19-40. https://doi.org/10.5296/ijld.v9i1.13786

Jain, A. K., \& Jeppesen, H. J. (2013). Knowledge management practices in a public sector organisation: The role of leaders' cognitive styles. Journal of Knowledge Management, 17(3), 347-362. https://doi.org/10.1108/JKM-11-2012-0358

Jain, P. (2015). Knowledge management leadership and decision making: A case of academic libraries. Department of Library \& Information Studies University of Botswana Gaborone, Botswana.

Kaiser, D. B., Köhler, T., \& Weith, T. (2016). Knowledge management in sustainability research projects: Concepts, effective models, and examples in a multi-stakeholder environment. Applied Environmental Education \& Communication, 15(1), 4-17. https://doi.org/10.1080/1533015X.2016.1141720

Karabetyan, L. (2019). Örgütsel öğrenme, bilgi yönetimi ve inovasyonun örgütsel performansa etkisi: hizmet işletmelerinde bir uygulama (Yayımlanmamış doktora tezi). İstanbul Arel Üniversitesi, İstanbul.

Karakoç, R. (2010). Okul yöneticilerinin bilgi yönetimi sürecini etkili kullanabilme becerileri ile liderlik stilleri arasındaki ilişki (Ankara ili örneği) (Yayımlanmamış yüksek lisans tezi). Gazi Üniversitesi, Ankara.

Karasar, N. (1999). Bilimsel araştırma yöntemi. Nobel Yayınevi.

King, W. R. (2009). Knowledge management and organizational learning: 4 (Annals of information systems). Retrieved from https://www.uky.edu/ gmswan3/575/KM_and_OL.pdf

Kok, J. A. (2003). Role of leadership in the management of corporate knowledge. South African Journal of Information Management, 5(3), 1-15.

Kurniawan, Y. (2014). The role of knowledge management system in school: perception of applications and benefits. Journal of Theoretical and Applied Information Technology, 61(1), 169-174.

Lakshman, C. (2007). Organizational knowledge leadership: A grounded theory approach. Leadership \& Organization Development Journal, 28(1), 51-75. https://doi.org/10.1108/01437730710718245

Lakshman, C. (2009). Organizational knowledge leadership: An empirical examination of knowledge management by top executive leaders. Leadership \& Organization Development Journal, 30(4), 338-364. https://dx.doi.org/10.1108/01437730910961676 
López, V. M. (2013). Leadership in organization knowledge to Mexico. ProcediaSocial and Behavioral Sciences, 73, 661-668. https://dx.doi.org/10.1016/j.sbspro.2013.02.103

Mas-Machuca, M. (2014). The role of leadership: The challenge of knowledge management and learning in knowledge-intensive organizations. Journal of Educational Leadership and Management, 2(1), 97-116. https://dx.doi.org/10.4471/ijelm.2014.10

Memisoglu, S. P. (2016). Teachers' and administrators' perceptions of knowledge management competence of high school administrators. Educational Research and Reviews, 11(4), 125-133. http://dx.doi.org/10.5897/ERR2015.2558

Micić, R. (2015). Leadership role in certain phases of knowledge management processes. Scientific Review Article, 61(4), 47-56. https://doi.org/10.5937/ekonomika1504047M

Mohajan, H. (2017). The roles of knowledge management for the development of organizations. Journal of Scientific Achievements, 2(2), 1-27.

Montgomery, A. (2012). Organizational learning and knowledge management in the NHSBT: An evaluation of the impact a geographically dispersed, multi-functional organisation has on the ability to learn and share knowledge. Bolton Business School, the University of Bolton.

Muhammed, S., \& Zaim, H. (2020). Peer knowledge sharing and organizational performance: The role of leadership support and knowledge management success. Journal of Knowledge Management, 24(10), 2455-2489. https://doi.org/10.1108/JKM-03-2020-0227

Muratoğlu, V. (2005). Eğitim örgütlerinde bilgi yönetimi stratejileri (Yayımlanmamış yüksek lisans tezi). Frat Ünüversitesi, Elazığ.

Özdemirci, F., \& Aydın, C. (2007). Kurumsal bilgi kaynakları ve bilgi yönetimi. Türk Kütüphaneciliği 21(2), 164-185.

Özgözgü, S., \& Atılgan, H. (2017). Liderlik stilleri, örgüt kültürü ve bilgi yönetimi ilişkisi. Kastamonu Eğitim Dergisi, 25(4), 1301-1318.

Özmen, F. (2010). The capabilities of the educational organizations in making use of tacit knowledge. Procedia Social and Behavioral Sciences, 9, 1860-1865. https://doi.org/10.1016/j.sbspro.2010.12.414

Özmen, F., \& Muratoglu, V. (2010). The competency levels of school principals in implementing knowledge management strategies the views of principals and teachers according to gender variable. Procedia Social and Behavioral Sciences 2, 5370-5376. https://doi.org/10.1016/j.sbspro.2010.03.875

Özsarıkamış, S. (2009). Ilköğretim okulu yöneticilerinin bilgi yönetimi yeterlikleri (Yayımlanmamış yüksek lisans tezi). Abant İzzet Baysal Üniversitesi, Bolu.

Rowley, J. (2000). Is higher education ready for knowledge management? The International Journal of Educational Management, 14(7), 325-333.

Sakarya, M. (2006). İlköğretim okulu yöneticilerinin bilgi yönetimindeki yeterlikleri (Yayımlanmamış yüksek lisans tezi). Selçuk Üniversitesi, Konya. 
Sandström, M., Stockinger, F., \& Vilmark, C. (2017). Leadership behaviours and its influence on knowledge management (Bachelor thesis in business administration). Mälardalens University, Västerås.

Singh, S. K. (2011). Leadership and organizational learning in knowledge management practices in global organizations. The Indian Journal of Industrial Relations, 47(2), 353-365.

Sönmez Çakır, F., \& Adıgüzel, Z. (2020). Analysis of leader effectiveness in organization and knowledge sharing behavior on employees and organization. SAGE Open, 10(1), 1-14. https://doi.org/10.1177/2158244020914634

Sprinkle, T. A., \& Urick, M. J. (2018). Three generational issues in organizational learning Knowledge management, perspectives on training and "low-stakes" development. The Learning Organization, 25(2), 102-112. https://doi.org/10.1108/TLO-02-2017-0021

Stylianou, V., \& Savva, A. (2016). Investigating the knowledge management culture. Universal Journal of Educational Research, 4(7), 1515-1521. https://doi.org/10.13189/ujer.2016.040703

Şahin, C. (2010). Illköğretim okullarındaki müdürlerin bilgi yönetimi becerileri ile okulların öğrenen örgüt olma düzeyleri arasındaki ilişki (Ankara ili örneği) (Yayımlanmamış yüksek lisans tezi). Gazi Üniversitesi, Ankara.

Thambi, M., \& O'Toole, P. (2012). Applying a knowledge management taxonomy to secondary schools. School Leadership \& Management, 32(1), 91-102. https://doi.org/10.1080/13632434.2011.642350

The Wallace Foundation. (2013). The school principal as leader: guiding schools to better teaching and learning. www.wallacefoundation.org. New York.

Üzüm, S. (2009). Resmi ilköğretim okullarında örgütsel öğrenme aracı olarak bilgi yönetimi (Yayımlanmamış yüksek lisans tezi). Beykent Üniversitesi, İstanbul.

Viitala, R. (2004). Towards knowledge leadership. The Leadership \& Organization Development Journal, 25(6), 528-544.

Williams, P. (2012). The role of leadership in learning and knowledge for integration. Journal of Integrated Care, 20(3), 164-174. https://doi.org/10.1108/14769011211237500

Yang, L., Huang, C., \& Hsu, T. (2014). Knowledge leadership to improve project and organizational performance. International Journal of Project Management, 32(1), 40-53. https://doi.org/10.1016/j.ijproman.2013.01.011

Yılmaz, H. (2014). Bilgi liderliğinin işletme performansı üzerine etkilerinin değerlendirilmesi. Optimum Ekonomi ve Yönetim Bilimleri Dergisi, 1(1), 51-68.

Zaim, H., Kurt, İ., \& Seçgin, G. (2012). Örtülü bilginin performansa etkisi: Uluslararas1 bir banka uygulaması. İstanbul Ticaret Üniversitesi Sosyal Bilimler Dergisi, 11(21), 425-442.

This is an Open Access article distributed under the terms of the Creative CommonsAttributionNonCommercial-ShareAlike 4.0 International (CC BY-NC-SA 4.0). For further information, you can refer to https://creativecommons.org/licenses/by-nc-sa/4.0/ 